\title{
Pengaruh Media Virtual Reality Berbantuan Google Cardboard Terhadap Kemampuan Menulis Puisi Siswa Kelas X SMA Assa'adah Bungah Gresik Tahun Ajaran 2019/2020
}

\author{
Fina Nabilah Layaliya ${ }^{1)}$,Abdul Rosid ${ }^{2)}$, Ahmad Jami'ul Amil ${ }^{3)}$ \\ finan.layaliya@gmail.com ${ }^{1)}$, abdulrosid1045@gmail.com ${ }^{2)}$, ahmadamil@trunojoyo.ac.id ${ }^{3)}$ \\ Universitas Trunojoyo Madura ${ }^{1) 23)}$
}

\begin{abstract}
Abstrak. Penelitian ini dilatarbelakangi oleh kesulitan siswa dalam menuangkan ide menjadi sebuah karya tulis puisi serta kurangnya pemanfaatan media dalam pembelajaran. Rumusan masalah pada penelitian ini yakni bagaimanakah pengaruh media virtual reality berbantuan google cardboard terhadap keterampilan menulis puisi siswa kelas X SMA Assa'adah Bungah Gresik tahun ajaran 2019/2020. Jenis penelitian kuantitatif dengan perencanaan penelitian Quasi Eksperimental Design. Populasi penelitian ini adalah siswa kelas X SMA Assa'adah Bungah Gresik tahun ajaran 2019/2020, dengan sampel sebanyak 2 kelas. Teknik pengumpulan data menggunakan teknik observasi keterlaksanaan pembelajaran, tes, angket, dan dokumentasi. Analisis data tes keterampilan menulis puisi menggunakan uji normalitas, uji homogenitas, dan uji hipotesis (uji signifikansi). Hasil penelitian (1) Kemampuan menulis puisi kelas eksperimen saat pelaksanaan posttest lebih baik dari pada pelaksanaan pretest. (2) Terdapat pengaruh yang signifikan terhadap penggunaan media virtual reality berbantuan google cardboard terhadap kemampuan menulis puisi siswa. (3) Respons siswa terhadap media virtual reality berbantuan google cardboard sangat positif dengan memperoleh rata-rata 92,89\%. (4) Keterlaksanaan pembelajaran dengan media virtual reality berbantuan google cardboard memperoleh persentase $93 \%$ dengan kategori "sangat baik".
\end{abstract}

Kata kunci : google cardboard, keterampilan menulis puisi, media virtual reality.

\section{Pendahuluan}

Pendidikan terus mengalami perubahan dan perkembangan serasi dengan bidang kehidupan serta pergantian zaman. Pendidikan memiliki posisi yang begitu penting agar sumber daya manusia dapat ditingkatkan menuju arah yang lebih baik lagi. Pendidikan juga diharapkan mampu membentuk siswa yang dapat mengembangkan sikap, keterampilan, dan kecerdasan serta karakter. Pendidikan tentunya tidak lepas dari kegiatan pembelajaran. Pembelajaran sangatlah penting bagi manusia. Adanya proses pembelajaran akan mampu menjadikan manusia berkembang, berintelektual, dan berkarakter.

Belajar dapat terjadi karena ada subjek yang mengajar dan subjek yang belajar. Guru dalam proses pembelajaran disebut sebagai subjek yang mengajar, sedangkan subjek yang belajar disebut siswa. Adanya pembelajaran bahasa dimungkinkan manusia untuk saling berkomunikasi. Berdasarkan pendekatan saintifik, pembelajaran bahasa Indonesia memiliki tujuan menaikkan/mempertinggi kecakapan dalam proses pemikiran, khususnya kemampuan berpikir tingkat tinggi pada siswa (Riwan Putri Bintari et al., 2014).

Menulis menjadi satu di antara keterampilan berbahasa. Dalam keterampilan menulis, siswa dituntut untuk dapat menyusun kalimat ke dalam formulasi bahasa tulis. Keterampilan menulis tidak hanya cukup dipelajari melalui teori, tetapi harus dilaksanakan dengan cara praktik atau latihan. Keterampilan menulis dalam Kegiatan Belajar Mengajar (KBM) salah satunya dengan menulis karya sastra yaitu puisi. Puisi dapat disebut sebagai bentuk ekspresi sesorang dalam berimajinasi dan disusun dengan bahasa yang indah. Latihan menulis puisi sangatlah 
penting untuk mempertajam kemampuan berbahasa, selain itu juga dapat mempertajam daya imajinasi siswa. Dalam proses kreatif menulis puisi, penulis membutuhkan penunjang atau media yang dapat merangsang kepekaan dan daya imajinasi. Penggunaan media juga sangat membantu guru dalam memberikan materi pembelajaran. kreativitas seorang guru dan siswa dapat diasah dengan menggunakan media pembelajaran. Menurut Gerlach (Arsyad, 2013) secara garis besar media merupakan peristiwa/kejadian, materi, benda yang dapat membangkitkan kondisi yang menjadikan siswa mampu mengasah keterampilan, pengetahuan dan sikap.

Perkembangan teknologi informasi dan komunikasi berpengaruh dalam segala aspek kehidupan manusia, salah satunya didunia pendidikan, lebih khusus dalam proses belajar mengajar. Penggunaan media pembelajaran yang berbasis Teknologi Informasi (IT) menjadi tuntutan dalam penggunaanya. Walaupun membutuhkan keahlian khusus dalam merancang media berbasis IT, bukan berarti media tersebut dihindari dan ditinggalkan (Muhson, 2010). Penguasaan guru dalam aneka macam media lebih khusus media teknologi dapat dikatakan masih dangkal sehingga guru masih tidak sanggup mempergunakan media yang ada.

Salah satu perkembangan teknologi informasi dan komunikasi dalam dunia pembelajaran adalah adanya media virtual reality. (Pranata et al., 2017) mengungkapkan bahwa virtual reality merupakan teknologi berbasis komputer dimana pengguna dapat berinteraksi dengan lingkungan yang ada di dunia maya merasa berada pada dunia nyata. Perkembangan penggunaan virtual reality saat ini tidak hanya dengan menggunakan perangkat komputer saja, melainkan bisa menggunakan sistem android. Contoh teknologi virtual reality yang sangat sederhana ialah google cardboard yang pembuatanya menggunakan karton. Dilihat dari fungsinya Google cardboard belum begitu memiliki banyak fungsi, akan tetapi dengan memanfaatkan google cardboard pengguna virtual reality akan menikmati pengalaman virtual reality dengan cara mengikatkan smartphone yang mempunyai gyroscope pada google cardboard (Herlambang \& Aryoseto, 2016).

Pemanfaatan media virtual reality dalam pembelajaran bisa diterapkan dalam salah satu keterampilan berbahasa, menulis keterampilan. Menulis puisi merupakan salah satu materi pembelajaran bahasa Indonesia di kelas X SMA. Meskipun demikian, tidak banyak dari siswa kelas X yang mahir merangkai kata-kata untuk menulis puisi. Perlu adanya dorongan atau rangsangan untuk membuat siswa akhirnya terbiasa menulis sebuah puisi. Salah satu sekolah dengan materi menulis puisi pada kelas $X$ adalah SMA Assa'adah. SMA Assa'adah yang terletak di Kecamatan Bungah Kabupaten Gresik. Sejauh ini siswa Kelas X SMA Assa'adah tidak banyak yang mahir dalam menuangkan gagasan untuk menulis puisi. Siswa juga terkadang sulit memulai untuk menulis. Selain itu siswa kelas X SMA Assa'adah perlu adanya media untuk merangsang daya imajinasi mereka sehingga dengan mudah mereka memunculkan katakata untuk menulis puisi. Melihat permasalahan-permasalahan yang telah dipaparkan, diambilah bagaimanakah pengaruh media virtual reality berbantuan google cardboard terhadap kemampuan menulis puisi siswa kelas X SMA Assa'adah Bungah Gresik tahun ajaran 2019/2020 sebagai rumusan masalah. 
Metode yang digunakan adalah metode kuantitatif dengan perencanaan penelitian Quasi Eksperimental Design, sedangkan bentuk desain yang digunakan adalah Nonequivalent Control Group Design. Pada desain ini kelompok eksperimen maupun kontrol dibandingkan. Kelas eksperimen dan kontrol diberi pretest di awal untuk mengetahui perbedaan di awal. Selanjutnya kelas eksperimen diberi perlakuan saat posttest untuk mengetahui perbedaan di akhir. Pupulasi penelitian terdiri dari siswa kelas X SMA Assa'adah Bungah Gresik tahun ajaran 2019/2020 yang terdiri dari 68 siswa, yang digunakan sebagai sampel yakni X IPA 3 dengan jumlah 34 siswa sebagai kelompok eksperimen dan X IPS 1 dengan jumlah 34 siswa sebagai kelompok kontrol.

Dalam penelitian ini teknik pengumpulan data yang digunakan adalah tes, observasi keterlaksanaan pembelajaran, angket, dan dokumentasi. Instrumen penelitian berupa tes kemampuan menulis puisi siswa, lembar observasi keterlaksanaan pembelajaran, serta angket respons siswa yang digunakan untuk mengetahui respons siswa setelah mengikuti pembelajaran dengan media virtual reality berbantuan google cardboard.

UJi validitas dan reliabilitas digunakan sebagai teknik analisis data dengan tujuan mengetahui valid dan reliabel instrumen sebelum digunakan penelitian. Valid mengandung arti instrumen tersebut dapat digunakan sebagai pengukur yang harusnya diukur (Sugiyono, 2016). Selain itu, teknik analisis data tes keterampilan menulis terdiri atas 1) uji normalitas dengan kaidah pengujian jika $\mathrm{D}$ hitung $<\mathrm{D}$ tabel maka Ho diterima, 2) uji homogenitas dengan kriteria penilaian $\mathrm{F}$ hitung $\leq \mathrm{F}$ table maka Ho diterima, dan uji hipotesis (uji signifikansi) dengan kaidah pengujian $t_{\text {hitung }}>t$ tabel maka Ho ditolak dan Ha diterima.

\section{Hasil dan Pembahasan}

Sebelum perangkat penelitian digunakan, terlebih dahulu dilakukan uji validasi yang dilakukan oleh tiga validator. Hasil pengujian dinyatakan instrumen layak untuk digunakan. Selanjutnya uji coba instrumen di SMA Al Karimi Dukun Gresik pada kelas X IPA dengan jumlah 32 siswa. Hasil analisis uji validitas menunjukkan $r_{\text {hitung }}(0,659 ; 0,869 ; 0,682 ; 0,836$; $0,822)>r_{\text {tabel }}(0,349)$ sehingga dinyatakan valid. Instrumen juga dinyatakan reliabel dengan perolehan nilai alfa $>r_{\text {tabel }}(0,836>0,349)$. Berdasarkan valid dan reliabel instrumen maka layak untuk dilanjutkan pada tahap penelitian.

Observasi keterlaksanaan pembelajaran berlangsung di kelas X IPA 3 dengan jumlah 34 siswa pada kegiatan pembelajaran menggunakan media virtual reality berbantuan google cardboard. Rekapitulasi hasil pembelajaran diperoleh persentase $96 \%$ yang dikategorikan sangat baik. Angket diberikan pada kelas eksperimen yakni kelas X IPA 3 yang bertujuan untuk mengetahui respons siswa terhadap pembelajaran dengan menggunakan media virtual reality berbantuan google cardboard. Angket respons siswa berjumlah lima belas pernyataan yang terbagi ke dalam empat bagian.

Tabel 4.8 Hasil Analisis Angket Respons Siswa

\begin{tabular}{clcc}
\hline No. & \multicolumn{1}{c}{ Indikator } & Persentase & Kriteria \\
\hline 1. & Kemenarikan & $96 \%$ & Baik \\
2. & Kebermanfaatan & $91 \%$ & Sangat Baik
\end{tabular}


Deiksis: Jurnal Pendidikan Bahasa dan Sastra Indonesia, 7 (2) Juli 2020

3. Kejelasan dan Kesesuaian

$92 \%$

Baik

4. Kemudahan/ Mempermudah

$92 \%$

Sangat Baik

Rata-rata

$92.89 \%$

Sangat Baik

Berdasarkan tablel 4.8 diperoleh rata-rata dari persentase angket respons siswa yakni 92.89\% dengan kriteria sangat baik, dengan demikian memberikan arti bahwa siswa memperoleh kemudahan dan kebermanfaatan untuk menulis puisi dengan menggunakan media virtual reality berbantuan google cardboard. Selain itu pembelajaran menulis puisi dengan menggunakan media virtual reality berbantuan google cardboard juga menarik dan memberikan kesejelasan video serta sesuai dengan materi pembelajaran.

Gambar 4.1 Presentase Rata-rata Nilai Pretest Menulis puisi

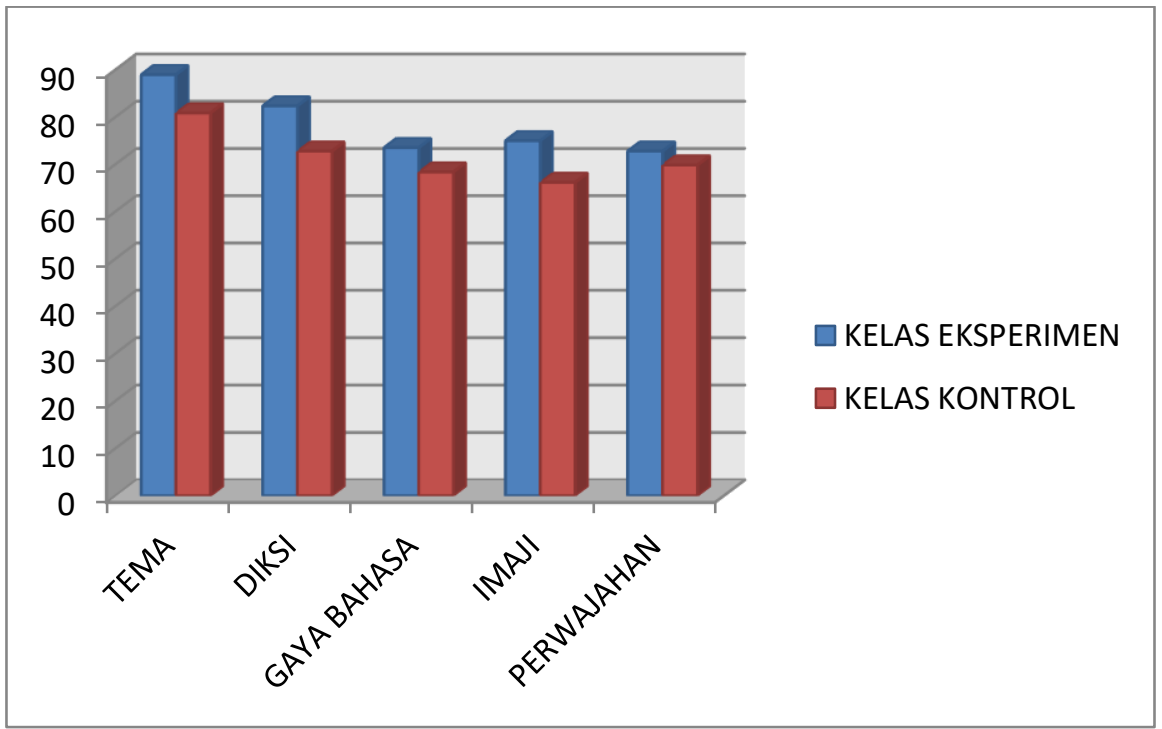

Berdasarkan gambar 4.1 di atas, nilai pada kelas eksperimen dijabarkan dengan persentase $88.97 \%$ siswa memperhatikan tema dalam penulisan puisi, $82.35 \%$ siswa memperhatikan diksi dalam puisi yang diciptakan, $73.52 \%$ siswa mmeperhatikan gaya bahasa dalam penulisan puisi, $75 \%$ siswa memperhatikan imaji dalam menciptakan puisi, dan $72.79 \%$ siswa memperhatikan perwajahan dalam penulisan puisi. Sedangkan nilai pada kelas kontrol dijabarkan dengan persentase $80.88 \%$ siswa memperhatikan tema dalam penulisan puisi, $72.79 \%$ siswa memperhatikan diksi dalam puisi yang diciptakan, $68.38 \%$ siswa memperhatikan gaya bahasa dalam penulisan puisi, $66.18 \%$ siswa memperhatikan imaji dalam menciptakan puisi, $69.85 \%$ siswa memperhatikan perwajahan dalam penulisan puisi.

Setelah pelaksanaan pretest siswa memperoleh materi dengan perlakuan menggunakan media virtual reality berbantuan google cardboard pada kelas eksperimen dan pembelajaran biasa pada kelas kontrol. Setelah itu dilanjut dengan pelaksanaan posttest guna mengukur keterampilan menulis puisi siswa setelah mendapat pembelajaran tersebut. 
Gambar 4.2 Presentase Rata-rata Nilai Posttest Menulis Puisi

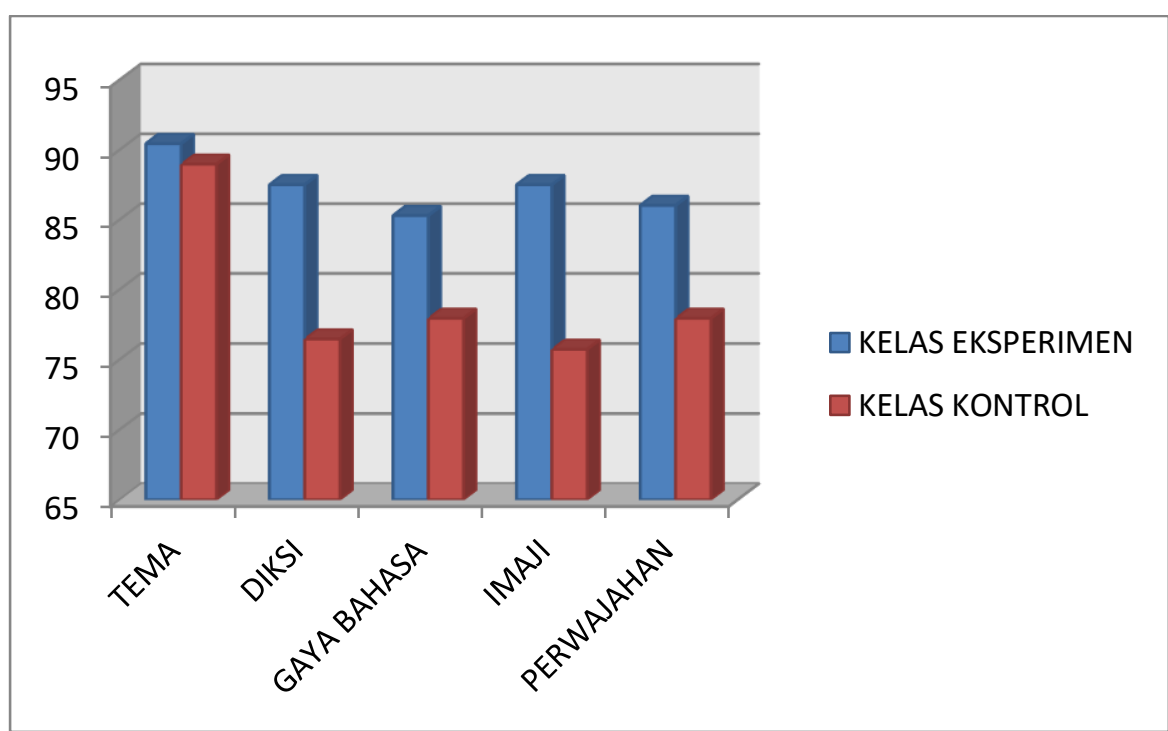

Berdasarkan gambar 4.2 di atas, nilai pada kelas eksperimen dijabarkan dengan persentase $90.44 \%$ siswa memperhatikan tema dalam penulisan puisi, $87.5 \%$ siswa memperhatikan diksi dalam puisi yang diciptakan, $85.29 \%$ siswa mmeperhatikan gaya bahasa dalam penulisan puisi, $87.5 \%$ siswa memperhatikan imaji dalam menciptakan puisi, dan $86.02 \%$ siswa memperhatikan perwajahan dalam penulisan puisi. Sedangkan nilai pada kelas kontrol dijabarkan dengan persentase $88.97 \%$ siswa memperhatikan tema dalam penulisan puisi, $76.47 \%$ siswa memperhatikan diksi dalam puisi yang diciptakan, $77.94 \%$ siswa mmeperhatikan gaya bahasa dalam penulisan puisi, $75.73 \%$ siswa memperhatikan imaji dalam menciptakan puisi, 77.94\% siswa memperhatikan perwajahan dalam penulisan puisi.

Dari hasil posttest pada kelas eksperimen siswa mengalami peningkatan dari sebelumnya. Hal ini dibuktikan dengan perolehan rata-rata pada kelas eksperimen yakni 87.35 dari yang sebelumnya yakni 78.53, dengan jumlah siswa memperoleh nilai tuntas sebanyak 29 dan jumlah siswa memperoleh nilai tidak tuntas sebanyak 5 siswa. Hal ini dikarenakan siswa mulai memperhatikan tema, diksi, gaya bahasa, imaji, dan perwajahan dalam menciptakan puisi dengan bantuan media virtual reality berbantaun google cardboard. Sedangkan pada kelas kontrol diperoleh rata-rata 78.82 dengan 8 siswa yang masih belum tuntas nilainya. Berdasarkan penjabaran di atas, siswa pada kelas eksperimen mengalamai peningkatan dalam menciptakan puisi dari pretest ke posttest. Siswa pada kelas eksperimen lebih terampil dalam menciptakan puisi dengan memperhatikan tema, diksi, gaya bahasa, imaji, dan perwajahan.

Berikutnya dilakukan uji normalitas menggunakan metode kolmogorof-smirnov dengan kaidah pengujian jika $\mathrm{D}$ hitung $\leq \mathrm{D}$ tabel maka Ho diterima. Uji Normalitas digunakan untuk mengetahui data berdistribusi normal atau tidak (Riduwan, 2013). Dari hasil analisis uji normalitas pretest menunjukkan bahwa kelas eksperimen dan kelas kontrol berdistribusi normal. Hal ini dibuktikan dengan $\mathrm{D}_{\text {hitung }}=0.228165565<\mathrm{D}_{\text {tabel }}=0.242$ pada kelas eksperimen dan $D_{\text {hitung }}=0.215442601<D_{\text {tabel }}=0.242$ pada kelas kontrol. Selain itu, hasil analisis uji normalitas posttest kelas eksperimen dan kelas kontrol juga berdistribusi normal. Hal ini dibuktikan dengan $\mathrm{D}_{\text {hitung }}=0.216401066<\mathrm{D}_{\text {tabel }}=0.242$ pada kelas eksperimen dan $\mathrm{D}_{\text {hitung }}=0.170036705<\mathrm{D}_{\text {tabel }}$ 
$=0.242$ pada kelas kontrol. Berdasarkan hasil tersebut dapat disimpulkan bahwa data kelas eksperimen dan kelas kontrol berdistribusi normal.

Berikutnya dilakukan uji homogenitas dengan kaidah pengujian apabila $F_{\text {hitung }} \leq F_{\text {tabel }}$ maka Ho diterima yang berarti tidak ada perbedaan varian antara kedua kelompok (data bersifat homogen). Berdasarkan hasil analisis uji homogenitas pada kelas eksperimen dan kelas kontrol baik saat pelaksanaan pretest dan posttest menunjukkan bahwa data bersifat homogen.

Setelah diketahui data berdistribusi normal dan homogen maka selanjutnya dilakukan uji hipotesis. Data yang digunakan untuk uji hipotesis adalah nilai pretest dan posttest kelas eksperimen. Dari hasil analisis diperoleh nilai $t_{\text {hitung }}=25.76267307>t_{\text {abel }}=0.8$ sehingga dapat dikatakan ada pengaruh signifikan pembelajaran menulis puisi menggunakan media virtual reality berbantuan google cardboard terhadap keterampilan menulis puisi siswa kelas X SMA Assa'adah Bungah Gresik.

Berdasarkan penelitian yang telah dilakukan dapat ditarik kesimpulan bahwa pembelajaran Bahasa Indonesia pada materi menulis puisi menggunakan media virtual reality berbantuan google cardboard memberikan pengaruh yang positif terhadap hasil keterampilan menulis puisi siswa. Hal tersebut dikarenakan siswa dapat mengembangkan keterampilan dan pengetahuan melalui pembelajaran yang dikaitkan dengan fenomena alam yakni pulau raja ampat dengan bantuan google cardboard dari virtual reality. Pembelajaran menggunakan media virtual reality berbantuan google cardboard juga mempunyai pengaruh yang signifikan terhadap keterampilan menulis puisi siwa. Selain itu, pembelajaran menggunakan media virtual reality berbantuan google cardboard juga membuat pembelajaran menulis puisi menjadi lebih mudah dan menarik.

\section{Simpulan}

Kemampuan menulis puisi kelas eksperimen saat pelaksanaan posttest lebih baik dari pada pelaksanaan pretest. Hal tersebut dibuktikan dengan nilai rata-rata saat pretest adalah 78.53 dengan jumlah siswa mendapat nilai tidak tuntas yakni 9. Saat posttest nilai rata-rata yakni 87.35 dengan jumlah siswa yang memperoleh nilai tidak tuntas 5 siswa. Terdapat pengaruh yang signifikan terhadap penggunaan media video virtual reality berbantuan google cardboard terhadap kemampuan menulis puisi siswa. Hal tersebut dibuktikan dengan uji hipotesis (uji tsignifikansi) dengan menggunakan taraf siginifikansi $(\alpha)=0.05, t_{\text {tabel }}=0,8$ dan $t_{\text {hitung }}=$ 25,7626730723, thitung > ttabel maka Ho ditolak dan Ha diterima.

Hasil penelitian ini hendaknya dapat dijadikan referensi guna memperbaiki penelitian dengan media virtual reality berbantuan google cardboard menggunakan lensa 3D yang asli serta kertas cardboard yang lebih baik sehingga media yang digunakan dalam proses pembelajaran akan lebih efektif dan maksimal. Tidak hanya itu, guru juga dapat menerapkan media virtual reality berbantuan google cardboard dalam pembelajaran menulis puisi siswa.

\section{Daftar Pustaka}

Arsyad, A. (2013). Media Pembelajaran. Jakarta: PT Raja Grafindo Persada.

Herlambang, P. M., \& Aryoseto, L. (2016). Potensi Virtual Reality Berbasis Smartphone sebagai Media Belajar Mahasiswa Kedokteran. Cdk, 43(6), 412-415. 
http://www.cdkjournal.com/index.php/CDK/article/view/67/64

Muhson, A. (2010). Pengembangan Media Pembelajaran Berbasis Teknologi Informasi. Jurnal Pendidikan Akuntansi Indonesia, 8(2). https://doi.org/10.21831/jpai.v8i2.949

Pranata, M. A., Santyadiputra, G. S., \& Sindu, I. G. P. (2017). Rancangan Game Balinese Fruit Shooter Berbasis Virtual Reality Sebagai Media Pembelajaran. Jurnal Nasional Pendidikan Teknik Informatika (JANAPATI), 6(3), 256-270. https://doi.org/10.23887/janapati.v6i3.11994

Riduwan. (2013). Dasar-dasar Statistika. Bandung: Alfabeta.

Riwan Putri Bintari, N. L. G., Sudiana, I. N., \& Bagus Putrayasa, I. (2014). Pembelajaran Bahasa Indonesia Berdasarkan Pendekatan Saintifik ( Problem Based Learning ) Sesuai Kurikulum 2013 Di Kelas Vii Smp Negeri 2 Amlapura. E- Journal Program Pascasarjana Universitas Pendidikan Ganesha, 3(1), 1-10.

Sugiyono. (2016). Metode Penelitian Kuantitatif Kualitatif dan $R \&$ D. Bandung: Alfabeta. 